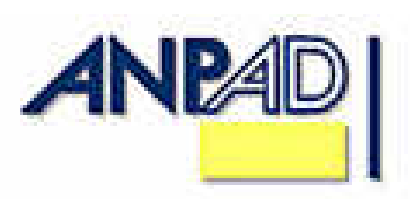

Available online at

http://www.anpad.org.br/bar

BAR, Curitiba, v. 5, n. 2, art. 2, p. 104-124,

Apr./June 2008

\title{
Development: an Analysis of Concepts, Measurement and Indicators
}

\author{
Jair Soares Jr. * \\ E-mail address: jairsoaresjr@yahoo.com.br \\ Escola de Administração, Universidade Federal da Bahia \\ Salvador, BA, Brazil. \\ Rogério H. Quintella \\ E-mail address: rhquintella@gmail.com \\ Escola de Administração, Universidade Federal da Bahia \\ Salvador, BA, Brazil.
}

\begin{abstract}
This paper presents the result of a comprehensive analysis of the main forms of development measurement. Recognizing the level of complexity that the subject involves, aspects related to interpretations and dominant ideologies in development/growth concepts are shown initially. The second part of this work constitutes a critical analysis of forty-three of the most well-known national and international indicators used to measure this phenomenon. It is imagined that this analysis can show the state of the art for constructing development indicators. The development process covers a complexity of relationships. Its analysis, therefore, cannot be restricted only to the economic dimension because, as a rule, the question is presented both in the media and a considerable part of specialized literature. Emphasis on this dimension has historic origins, which have already shown the fragility of this approach.
\end{abstract}

Key words: development; development indicators; index; well-being.

Received 12 February 2008; received in revised form 28 April 2008.

Copyright (c) 2008 Brazilian Administration Review. All rights reserved, including rights for translation. Parts of this work may be quoted without prior knowledge on the condition that the source is identified.

* Corresponding author: Jair Soares Jr.

Núcleo de Pós-Graduação em Administração (NPGA), Universidade Federal da Bahia (UFBA), Av. Reitor Miguel Calmon, s/n, $3^{\circ}$ andar, Canela, Salvador/BA, 41110-903, Brazil. 


\section{HISTORIC DETERMINANTS OF DEVELOPMENT: FROM THE $17^{\text {TH }}$ TO $19^{\text {TH }}$ CENTURY}

The concept of development is almost as old as civilization. Its extensive use in western societies from Greco-Roman civilizations to the late $19^{\text {th }}$ century as a generic construct that designates the most varied aspects related to humanity's well-being, however, made the concept come closer to that of a doctrine. For this present study's purposes, a temporal cut was chosen from $17^{\text {th }}$ century illuminist ideas and its metamorphoses until current times.

At the end of that century, the predominant idea of development was dependent on natural and positive phenomena, with its expansion only contained by conscience of limit ${ }^{(1)}$. Following a long dispute between those called the Modern and Ancient, ending with victory by the Modern, Leibniz (1646-1716) inaugurated the concept of infinite progress.

Other modern thinkers such as Condorcet, Kant, Hegel and Marx in turn conceived and interpreted progress in a distinct manner from that resulting from the idea of conscience of limit or, in other words, are aligned with the potentially infinite concept of progress. In these authors' works, it is also possible to note a certain proximity with Augustinian thinking, of conceiving history as a totality, a firm march of civilization, a continual, albeit inconstant and non-linear process, in the direction of a common well-being. In Rist's words: "a constant evolution, based on the belief of human perfectibility and motivated by the incessant search for well-being" (Rist, 2001, p. 70).

In the mid $18^{\text {th }}$ century, radically opposing the Rousseaunian vision of the good savage ${ }^{(2)}$, Buffon (1707-1788) defended the idea that there is a general prototype for each species in nature and that this is perfected because of the climate and habits of the society in which it is inserted. In his work Natural History, the author defends the idea that civilization will arrive at the European and affirms: "Because of their superiority, civilized people are responsible for the coming world" (Buffon as cited in Duchet, 1984, p. 54). In this way, Buffon almost gives the force of law to what he perceives as a historic reality.

Also in the $18^{\text {th }}$ century, the Marquis of Condorcet (1743-1794), launched the bases of thinking that would predominate in the second half of the $20^{\text {th }}$ century, in defending the idea that Europeans would end up respecting the independence of their ex-colonies and, then, should contribute to them through civilizing their people ${ }^{(3)}$ (Rist, 2001, p. 68). Another paradigm of development, however, had already reached its peak in the $19^{\text {th }}$ century, under the form of Social Evolutionism. The term development, in this new paradigm, prevailed on concepts such as modernization or liberation. Such predominance seems to result from the need for a broader concept to represent the multiple dimensions necessary for humanity's well-being.

An apparent alignment of modernity theories can now be highlighted in the sense of perceiving social groups as a unique species and therefore presenting similar development paths. However, recurrent analogy with the natural development processes does not explain and is not even able to adequately deal with the cultural multiplicity present in societies, particularly in the $20^{\text {th }}$ and $21^{\text {st }}$ centuries, as will be discussed later on in this paper.

\section{0th Century DeVelopment: the Perspective of INTERnational Agencies}

The growing diffusion of development concepts and policies permits the last decades to be nominated here as the era of development. The origin of this era, in which we supposedly still live, can be located at the end of the first half of the $20^{\text {th }}$ century, possibly in North American President Harry $S$ Truman's international policy, when he decided to highlight the importance of extending the technical help offered to some Latin American and other less-favoured nations: 
I believe that we should make available to peace loving peoples the benefits of our store of technical knowledge in order to help them realize their aspirations for a better life. And, in cooperation with other nations, we should foster capital investment in areas needing development (Truman, 1949).

The Marquis of Condocert's aforementioned ideas can therefore be compared with a new international situation. 1960 is considered to be the year of decolonization, a process, which until then had been legitimized purely as a generous agreement aiming to offer opportunity to societies that were considered the slowest to advance on the path of civilization.

Several countries became independent from that moment and the supposed decolonization process crossed the world. This even changed the relationship of forces in the United Nations plenary session and apparently placed the problems of world inequality and the need for development in what was then called the Third World at a higher level.

The development question took on new shapes and slants a little later in December, 1964 with the creation of the United Nations Conference on Trade and Development [UNCTAD]. This organization was created with the objective of attempting to bridge the gap, which was not covered by the organizations that appeared following the Second World War.

Another international milestone in development question took place in 1968, with the creation of the Rome Club. This brought together professionals from various areas and different countries to form a free association of scientists, technocrats and politicians, whose objective was to reflect on and seek solutions to various world problems. This new forum published a report entitled Growth Limits in 1972, in which it recognizes the finitude of natural resources and the seriousness of the problems that were already devastating the environment and jeopardizing human survival on Earth. Some of the development phenomenon's new dimensions acquired space and legitimacy in this way.

Also in that year, at the United Nations Conference on Environment and Development [UNCED], held in Stockholm, the growing international movement on the topic highlighted the problem of the possible lack of a continual energy supply on the planet.

In the following decade, the central countries' actions extended domination of financial questions on the international development agenda through promoting neo-liberal ideas and practices of exalting the market and reducing the State. As a consequence, the Third World stopped gaining space on the world political agenda and now its development controversies did not find the same echo in priorities from the more economically developed countries.

In general, the Bretton Woods institutions, Organization for Cooperation and Economic Development [OCED] and World Trade Organization gained relevance in relation to UNCTAD. This organization was intended to be the main negotiation forum for a new international economic order in the 1970s (Almeida, 1994).

The World Commission for Environment and Development published a report entitled Our Common Future in 1987, also known as the Bruntland Report, which was an instrument used to spread the recently created concept of sustainable development.

In the 1990s, the United Nations Conference on the Environment and Development (Eco-92), held in Rio de Janeiro, brought the topic back to the international political agenda. It now dealt with advance as a much broader concept of development, adding environmental preservation and rational use of natural resources as imperative in resolving social and economic growth problems. Despite conflicts of interest at this conference, a long-term action programme was prepared, which had ample potential for international impact: Agenda 21. This agenda launched some of the bases to be practised and, in global terms, the new concept of sustainable development.

Eco-92 results unfolded in terms of measurement tools from August 1994, with the Conference and Workshop on Indicators of Sustainability [CWIS] taking place. According to Hart (1994), although some methodology conception initiatives already existed to apply measurement tools, the CWIS 
enabled some advances, among which the following are highlighted: a) recognition of different sustainability definitions; b) need for an appropriate methodology for effective sustainability indicator use and c) observation of governmental and private interests on the theme.

Also in that decade, institutions such as the World Resources Institute and World Bank promoted the spread of a green economy (green national accounting). This suggested methodological alterations that incorporated variables related to the use of natural resources (forests, rivers, lakes, etc) in the National Accounts System and, consequently, GDP calculation. To measure the 'green economy' in 1995, the World Bank carried out an evaluation of 192 countries and concluded that the physical capital, also measured by conventional GDP, on average corresponded to only $16 \%$ of the total wealth produced by these nations. However, human capital reached $64 \%$ and, natural capital, on average, represented 20\% of the total. According to Marzall and Almeida (1998), from this perspective, some European countries' GDP began to reflect a decrease in natural resources and the costs of pollution generated.

Between the end of the decade and start of the new millennium, globalization became the most important phenomenon in debates and reflections on international problems of a political, economic, social, cultural and environmental order. Among other factors, the extraordinary expansion of information content in the daily lives of many societies came into force as a hegemonic and determining standard for the so called Society of Information and Knowledge (Castells, 2000). This favoured proliferation of the western idea of development, assuming a new complexity and inciting challenges for researchers in the field.

With the objective of clarifying some contemporary questions on the concept of development, the next item brings some relevant definitions and then presents a structured analysis of the actual predominant currents when approaching development.

\section{CONTEMPORARY SENSES OF DEVELOPMENT}

Rostow's seminal work (1971) reclaims Social Darwinism to explain development as a process of evolutional succession in stages, where human societies leave a rudimentary model until they arrive at a western industrialized civilization consumption model, which is considered unique and universal.

In Ribeiro's approach (2005, p. 11), the sense of the word development, in various areas of knowledge, converges to "a state, process, well-being, progress, economic and human growth or ecological balance". The South Commision [SUD] (1990, p. 10) defines the term as "a maturing and development process of self that frees the population from fear and exploitation". Both understandings seem to diverge and advance in relation to the idea by the most traditional students of the theme to whom development is usually seen as a phenomenon that fundamentally interests developed countries (Ribeiro, 2005).

An international institutional vision such as that of United Nations Development Programme [UNDP] (1991, p. 77), on the other hand, also suggests an interpretation of what development is: "expanding the range of choices for the population that allows development to become more democratic and participative. (...) access to (sic) income... participation in decisions and enjoyment of human, economic and political liberties".

The three definitions presented so far are linked to models identified from three predominant currents when approaching the concept of development. The first, and more usual, deals with the term as a synonym for economic growth. The second denies that the term is appropriate and says that its use does not go beyond mere illusion, ideological manipulation, belief or myth. The third, and most difficult and challenging way, however, "tries to explain that development is not chimerical and also 
cannot be belittled as economic growth" (Veiga, 2005, p. 17). Each one of these schools of thought are described succinctly as follows:

\section{Development as Economic Growth}

From an economic perspective, Schumpeter $(1984,1985,1989)$ cannot be left unmentioned. He used the term development as evolution, unfolding, revelation and innovation.

For this school, it seems that there is no need for a development theory, applying modern economics to the concept, which is an antihistorical and universally valid discipline being sufficient. According to Veiga (2005, p. 80): "The market fundamentalists implicitly consider development as something redundant. Development would come as a natural consequence of economic growth, thanks to the trickle-down effect”.

Until several decades ago, some of the representative principles from the economic school of thought considered that growth would be capable of promoting society's development ${ }^{(4)}$. Supposedly with this, directly or indirectly solving problems arising from the most varied dimensions, mainly those related to poverty reduction of nations and regions. Facing the impossibility of population control, growth policies would be an alternative to combat poverty. Contemplated for centuries (Smith \& Ricardo, 1978), these policies still find support in recent literature on development (Bustelo, 1999; Preston, 1996) and are based on the idea that an economy, as it grows, makes for greater availability of resources for the population, thus benefiting the poorest.

The authors who form part of this current of thought defend the idea that in urbanized modern societies, a good part of well-being is associated to income that people have in order to access goods and services to be acquired in the market. This is a positioning that directly reflects in the formulation of social and environmental policies. However, despite the theoretic importance of this line of thought, the World Bank recognizes that only obtaining economic growth in itself does not guarantee poverty reduction.

\section{Development as Fiction}

In the discourse by authors forming part of this second current, the critique that development cannot be reduced to a quantitative understanding of the world is present. Rivero (2002) defends the idea that those who believe in development ignore the historical-cultural processes, society's non-linear progress, ethical approaches and even dispense with ecological impacts.

Another point that characterizes the authors forming part of this current scepticism is related to the fact of believing that a reduced, or almost non-existent, possibility exists of peripheral countries rising in the rigid world capitalist hierarchy.

According to Rist (2001), critical reflection has room for an economic vision of development when considering that societies form part of the same species, whose time elapses in the same rhythm for all: how would it be possible for a society that started its development later on, to reach those that are already at an advanced development stage?

Regarding use of the term development, critics converge in this way in understanding that imagining it as a simple asynthotic representation of growth is not appropriate, since this reasoning connects a natural to a social phenomenon in a simplistic form. Rist (2001) confirms this, saying that instead of facilitating the phenomenon's comprehension, the metaphor obscures it, naturalizing history. It would be as if each village was destined to become a great city or each animal species was destined to transform into another, as this presents greater evolutive success.

With the triumph of the Darwinist perspective in the $19^{\text {th }}$ century, Social Evolutionism came to be inserted into this debate until a new paradigm was established in the following century, where society 
would have the possibility of reaching perfection. Acceptance of this paradigm in the collective imaginary implied the acceptance of a supposed primacy of western superiority above other civilizations, among other things. In this way, at the heart of this concept would be the idea that a natural history of humanity exists and that, therefore, the development of societies, wealth and knowledge would correspond to a natural self-dynamic principle ${ }^{(5)}$.

The approximation of development theories with Darwinist ideas allowed for the legitimization of colonisation mainly in course in Africa and Asia at the end of the $19^{\text {th }}$ century on a political plane. It was a time in which this movement had the justification of providing colonized societies with the conditions to become advanced, in accordance with criteria established by this domination process. The benefits of this intervention materialized the idea that human nature is implied in social nature.

In direct opposition to this vision, Furtado $(1974$, p. 87) and others, defend the proposition that dependent countries would always be underdeveloped: "the transition of underdevelopment to development is hard to conceive, within the setting of dependency".

Corroborating the idea by this current's thinkers, Veiga (2005, p. 79) affirms that: "renunciation of the idea of development is due to the fact of having functioned as an ideological trap invented to perpetuate asymmetrical relationships between the dominant minorities and the dominated majorities in countries and among them".

Faced with the rejection of belief in development, part of this current's authors prefer to use the term economic development to the detriment of the more wide-ranging term.

Perhaps as a product of these currents' evident disagreement, a third school appeared and is discussed as follows.

\section{The 'Alternative' Route}

The third route brings together part of the authors from the sceptical current who believe that the multidisciplinary concept of development is complementary to the unidisciplinary idea of economic development. Veiga (2005, p. 81), for example, considers that Furtado has the best conception of the concept:

Economic growth such as we know it has been basing itself on preserving the elites' privileges that satisfy their enthusiasm for modernization; now development is characterized by its underlying social project. Having resources to invest is far from being a sufficient condition for preparing a better future for the mass population. However, when the social project prioritises effective improvement of this population's living conditions, growth metamorphasizes into development.

For this current, although economic growth can be transformed into development, there is no semantic equality between the terms. For development to take place, it is necessary that economic growth is thought of in the scope of a social project connected to society's well-being.

In view of the fragmentation of Social Sciences and the theoretical gap existent in the distinct development approaches, three basic principles are commonly attributed to the concept: efficiency, equity and liberty. Each one of these qualities, even if they are conceptually separate, is associated to three distinct planes: efficiency has an economic dimension in view, equity a social and liberty a political purpose (Universidade Estadual de Campinas [UNICAMP], 2005).

What is realized, however, is that to understand development as the defenders of the alternative route desire, an integrated and multidisciplinary view is necessary. Study of the phenomenon requires a new paradigm and, therefore, construction of new analytical categories, which integrate the contribution of other fields of science. 
The following section provides a brief description of these theoretical currents in the light of the still emerging concept of sustainability.

\section{SUSTAINABLE DEVELOPMENT}

The term sustainable development appeared in the late 1970s and was definitely consolidated in 1987 by the aforementioned Brundtland Commission. This commission prepared the most broadly accepted definition of sustainable development:

Sustainable development is a transformation process in which the exploitation of resources, direction of investments, orientation of technological development and institutional change are reconciled and reinforces present and future potential, in order to attend to needs and future aspirations (...) it is that which attends to present needs without compromising the possibility of future generations attending their own needs (Becker, 1993, p. 49).

Since then, this definition became the starting point for the inspirational theoretical mark of subsequent work (Matos, 1997).

Due to the increase of world political interest in environmental questions and incitement of socialenvironmental conflicts, there has been increased motivation for debate on the theme in the last few decades. As Sachs (2004) argues, it is in this context that the proposal of Sustainable Development appears as a desirable and possible alternative to promote social inclusion, economic well-being and preservation of natural resources.

Although a broad acceptance of the term sustainable had existed in the international community, it is also true that there is no consensus on a clear and unique definition for the concept. From an environmental perspective, the notion of sustainability "originates from theorizations and ecological practices that try to analyze the temporal evolution of natural resources, taking its persistence, maintenance or capacity of returning to a presumed state of balance after some type of disturbance as a basis" (Raynaut, Lana, \& Zanoni, 2000, p. 74).

According to Raynaut (1997, p. 370), use of this notion could lead to interpreting a history that does not fit in with other behaviour that is not "the immense reproduction of an impossible balance" of nature and society.

Veiga (2005) brings together answers to the question that by stating that it is sustainable in three distinct groups: 1 - Those that believe that economic theories could be perfected to respond to the environmental problem; 2 - Those that believe it is possible to reconcile economic growth and environmental conservation and 3 - Those that study the complementarities between economic development and development.

The ambiguity and lack of clarity, which are attributed to the sustainable development concept in Almeida's (1999) view, complicates the concept's operationalization, according to this author. For him, this difficulty has contributed to a worldwide and generalized acceptance of the principle of cultivating a sustainable character to development. In his perception, this would be a theoretical impossibility. For others, with the example of Naredo (1987), sustainability merely requires a standard of life within the limits imposed by nature. Using an economic metaphor, therefore, it should live within the capacity of natural capital.

Sustainable development, like any other conventional economic imperative, presupposes joining the maximization of economic production with social (minimizing current and future human suffering) and ecological (protecting the ecosphere) imperatives (Wackernagel \& Rees, 1996). 
Therefore, to understand the close relationship between sustainable development and themes of economic growth and the environment, it is fundamental to turn to the objects of study of at least three fields of knowledge:

. economic, social and human behaviour;

human geography and regional sciences;

. biological, physical and chemical sciences.

For Veiga (2005, p. 187) "It is evident that these three scopes are related, interact and overlap, mutually affecting and conditioning each other". Confirming Veiga's ideas, Sunkel (2001, p. 296) considers that "the evolution and transformation of society and the economy in the development process alter the natural world in various ways. This reciprocal relationship is materialized, articulated and expressed through concrete forms of territorial ordering".

It is in this same perspective that Sachs (2004) makes some basic principles of this new developmental vision clear:

. satisfying basic needs;

. solidarity with future generations;

. participation by the population involved;

. preservation of natural resources and the environment in general;

- preparation of a social system that guarantees employment, social security and respect for other cultures; and

. education programmes.

Other authors expand the range of analytical dimensions for sustainable development. For example, Darolt (2000) also analyses the question of sustainability, however, adding the sophistication of a division into five sub-dimensions: socio-cultural, technical-agronomic, economic, ecological and political-institutional.

On the other hand, the work of Camino and Müller (1993) also points to the expansion of sustainability's scope and includes: social justice, economic viability, environmental sustainability, democracy, solidarity and ethics.

In another approach, Lopes (2001) suggests that a multi-dimensional study should be turned to in the debate on developmental sustainability, focusing on the interconnections between social, economic and environmental dimensions and these with other dimensions, such as political, cultural, institutional and democratic.

\section{Well-being as a Variable Objective of Development}

As observed, the majority of approaches presented here consider the relationship and interaction between the parts of the whole and between the whole and its environment as a secondary element. However, this seems more evident in those approaches that suppose the existence of social, economic and environmental systems as separated and independent instances.

Definition of the dimensions adopted in analysis by the above-mentioned authors is, therefore, quite idiosyncratic, converging on some points and diverging on others, with the selected dimensions related to and derived from the context and objectives of each study. Therefore when discussing sustainable development, it is possible to identify a clear need for a multi-dimensional approach that considers the concept's operationalizaton, focusing on the interconnections between the more traditionally 
considered group of dimensions (social, economic and environmental) with those that emerge as a product of the concept's growing diffusion by distinct fields of knowledge (political, cultural, institutional etc). In this way, the viabilization of convergence metrics should be sought in a principle that permits the harmonization of concerns with people's well-being and the environment.

In this sense, we see that despite originally being used in human development studies, use of the term well-being is relatively recent in work on sustainability. Work such as that by Hodge, Holtz, Smith and Baxter (1995), Imbach, Dudley, Ortiz and Sánchez (1997) and Prescott-Allen (1997, 2001) brings as a hypothesis underlying the idea that sustainable development is something that takes place through a combination of human and the ecosystem's well-being. People live in and form part of the ecosystem and, consequently, analysis of the well-being of both cannot be carried out separately, i.e. the well-being of the natural environment does not make sense without human dimensions (political, economic and social) and humanity's well-being cannot be disassociated from the environment.

The term well-being, used in the sphere of sustainable development, is dealt with by Holtz (1995) from the dimensions: Economic, Human Development, Quality of Life, Health and Happiness. The first three dimensions are quite well-known in the literature on the subject and its indicators which are accepted around the world, for example: i) Income; ii) Human Development Index [HDI] and iii) Quality of Life Index [QLI]. However, the author deals with the Happiness and Health dimensions in a subjective manner.

In turn, discussion on well-being seems to maintain a certain affinity with Sen's (1976) proposed analysis of poverty, when focusing on capacities. In this approach, the author points out that it is relevant for people to have certain means available to achieve their objectives of well-being. He also defends the idea that these means could be physical conditions of life, human capital, political freedom, social rights, self-respect and wealth.

Whoever is deprived of the means that are considered basic is therefore classified as poor because he is not capable of satisfying his needs in the way that he desires. This criterion values the importance of people's freedom to decide on the use of the means that they have at their disposal in a way that is appropriate for them. Critics of this way of considering poverty basically relapse on two difficulties: defining what the minimum capacities are and evaluating the extent of freedom necessary for its use. For Ribeiro (2005, p. 6) "the seduction implicit in discussing development is belief in the possibility of eliminating poverty".

Faced with the definitions of development and sustainability presented, it could be said that sustainable is development that provides or allows for the condition of the harmonious maintenance of man's well-being (economic, social and political) and the environment (ecosystem and space) to be attained. Based on this referential and recognizing the importance of adhering to concept indicators, as well as the relevance of a multidimensional approach to the phenomenon, the main indicators and development indices available in literature are critically presented as follows.

\section{DEVELOPMENT METRICS AND THEIR DYNAMICS}

Contemporary society produces and stores data and information at a rate that was unimaginable until recently. Evolution of information technology noted in the evolution of computer packages and, mainly, the volume and availability of data offers an unequalled possibility to calculate a large number of indices. These allow for comparisons between countries, States, local authorities or even census units (usually much smaller than neighbourhoods). Facing this reality, it is important to emphasize the absolute necessity of coherence between the theoretical approaches and modelling implicit when constructing any indicator. The approach used in this research also aims to allow for reflection on the sources and variables used in constructing such indices, as well as the statistical models and measurements used in them. 
Various important pieces of work that deal with measuring development currently do this considering monitoring cases of 'accelerated social change' and, parallel to an almost colonial concept of well-being. The purpose of a large part of these development indicators is not only to show the relationship between facts and changes in a succinct form but also to subsidize the monitoring of the transformation processes of an economic, political, social, environmental, nature, etc.

The first studies on such indicators appeared in the United States during the 1960s. The great difficulty found at that time, however, was the insufficiency of data and lack of more robust methodologies to measure social phenomena. The initial failure of those studies was attributed to the lack of "statistics, statistical series and all other forms of evidence" (Bauer, 1996, p. 1 as cited in Noll \& Zapf, 1994, p. 1).

In Brazil however, social indicators gained importance in the 1970s, when the Social Development Council [SDC] proposed the "construction of a social indicator system for the periodic production of information, attempting to consolidate and articulate various methodologies, including those recommended by the UN" (Santagada, 1993, p. 250).

The various national and international efforts at metrics development still lacked solutions to problems of methodological and theoretic order in common in the 1980s, which contributed to a period of stagnation in this field of knowledge. At that time, many of the more industrialized countries diverted their attention from social policies, to the benefit of growing economic orientation of a more conservative character.

The fall of the Iron Curtain, the emergence of the European Union (among other political movements in the 1990s), allied with the need to monitor social transformations resulting from then, led to the resurfacing of interest in and possibilities for applying new metrics to subsidize decisionmaking by governments and public organizations. Noll and Zapf (1994, p. 13) see this period as being the "revival of social accounting and social modelling" necessary in order to arrive at explanatory models for the "linkages between different components and elements within a larger system".

For Beck (1997), the 1990s are the beginning of reflexive modernization and concepts of wellbeing and quality of life are reconsidered and related to new development ideas. It is in this decade that synthetic well-being indicators appeared, such as the Human Development Index and Index of Sustainable Development, mainly linked to greater public understanding and therefore for management/manipulation of so-called public opinion.

Faced with the complexity that the development theme presents, it can be seen that no group of indicators, however exhaustive that they may be, could measure and translate the phenomenon in its entirety. However, paths, proposals and methodologies can be perceived that allow for a better approximation with reality. Trzesniak (1998, p. 163) and others, defend the idea that "building good indicators is not trivial but can and must be done". In this author's understanding, the heart of this discussion would therefore be in making people aware of the conscious use of indicators and not merely denying their validity or using them in a naïve perspective.

As can be seen, discussions on development constitute a difficult and controversial field, which is open to multiple understanding and conceptions. Apart from the multiplicity of definitions on the phenomenon, the field of study also covers various ways of measuring and dealing with expressions of development and should adapt them to distinct realities and conceptualizations.

A conceptual and methodological debate is essential for producing metrics for any phenomenon, as the conception of different models implies different indicators (Maxwell, 1999). On the other hand, to measure development, the use of concepts, which accounts for their subjective, complex and multidimensional condition, is important and therefore does not cast aside social, economic, political and environmental knowledge. Based on these principles, this leads to an analysis of the most important development metrics as follows. 


\section{ANALYSIS OF THE MAIN DEVELOPMENT INDICATORS}

A brief survey on some of the questions that involve the concepts and forms of measuring development is made in this part of the paper, without intending to exhaust discussion.

Although the analysis proposed in this research is focused on a reflection of theoretical-conceptual aspects that permeate the construction of indicators, it is important to highlight that the use of indicators should also be based on technical and pragmatic criteria such as those defended by Tironi, Silva, Silva, Vianna and Médici (1991), Soares and Quintella (2002), Jannuzzi (2001) and Trzesniak (1998). Among the main criteria observed are the following indicator characteristics: relevance, intensity grading, univocity, standardization, traceability, stability, representativity and indicator simplicity.

As already mentioned, there are various practical and conceptual problems related to the processes and tools for measuring development. Initially, it was decided to point to some limitations of a more objective nature. The most important are availability, consistency and compatibility of data, as well as correct use of analytical techniques considered by financial, human and temporal resources involved. Apart from the above-mentioned problems, the importance of cultural ties that condition the decisionmaker's perspective and, eventually, its public during the respective decision-making processes and metric interpretation should also be highlighted.

Faced with such a challenge, each indicator or index was qualitatively analyzed using a theoreticalconceptual and methodological approach. This research centred on an analysis of 23 of the most important international indices or indicator systems, as well as 20 Brazilian indices or indicator systems, which are most widely known by the general public. This started with a systematic alignment study of these indicators with their respective theoretic referential.

To select the indices and indicator systems listed, a non-probable sample survey was carried out by trial, considering the following criteria: indicator adherence to the development concept such as the well-being of man (economic, social and political) and the environment (ecosystem and space); international acceptance and recognition; number of countries covered by the index and, finally, the historic moment in which the index was made public. Among the work that fits into the established conditions, the following can be highlighted:

\section{International Indicators}

Twenty-three internationally recognized indicators were selected for analysis ${ }^{(6)}$, listed in Table 1 where the analysis dimensions contained in them are highlighted. 
Table 1: Distribution of World Development Indices by Analysis

\begin{tabular}{|c|c|c|c|c|c|}
\hline \multirow{2}{*}{ Description } & \multicolumn{5}{|c|}{ Dimension } \\
\hline & Environmental & Economic & Political & Social & $\begin{array}{c}\text { Coverage } \\
\text { (Countries) }\end{array}$ \\
\hline $\begin{array}{l}\text { 1. Combined Consumption } \\
\text { Level Index (Bennett, 1951) }\end{array}$ & $\mathrm{X}$ & $\mathrm{X}$ & & $\mathrm{X}$ & 31 \\
\hline $\begin{array}{l}\text { 2. Human Resources } \\
\text { Development Index [HRDI] } \\
\text { (Harbison \& Myers, 1964) }\end{array}$ & & & & $\mathrm{X}$ & 75 \\
\hline $\begin{array}{l}\text { 3. Real Index of Consumption } \\
\text { (Beckerman \& Bacon, 1966) }\end{array}$ & & $X$ & & $\mathrm{X}$ & 80 \\
\hline $\begin{array}{l}\text { 4. UNRISD General Index of } \\
\text { Development [GID] } \\
\text { (McGranahan, Richard-Proust, } \\
\text { Sovani, \& Subramanian, 1972) }\end{array}$ & & $\mathrm{X}$ & & $X$ & 58 \\
\hline $\begin{array}{l}\text { 5. Physical Quality of Life } \\
\text { Index [PQLI] (Morris, 1979) }\end{array}$ & & & & $X$ & 150 \\
\hline $\begin{array}{l}\text { 6. Composite Basic Needs } \\
\text { Indices (Ram, 1982) }\end{array}$ & & $X$ & & $X$ & 82 \\
\hline $\begin{array}{l}\text { 7. World Handbook of } \\
\text { Political and Social Indicators } \\
\text { (Taylor \& Jodice, 1983) }\end{array}$ & & $\mathrm{X}$ & $\mathrm{X}$ & $X$ & 156 \\
\hline $\begin{array}{l}\text { 8. Index of Social Progress } \\
\text { [ISP] (Estes, 1984) }\end{array}$ & & $\mathrm{X}$ & $\mathrm{X}$ & $\mathrm{X}$ & 107 \\
\hline $\begin{array}{l}\text { 9. World Standart Distance } \\
\text { Scales (Ginsberg, Osborn, \& } \\
\text { Blank, 1986) }\end{array}$ & & $\mathrm{X}$ & & $\mathrm{X}$ & 143 \\
\hline $\begin{array}{l}\text { 10. Human Suffering Index } \\
\text { [HIS] (Camp \& Speidel, as } \\
\text { related in Hess, 1989). }\end{array}$ & & $\mathrm{X}$ & $\mathrm{X}$ & $X$ & $\begin{array}{l}\text { More than } \\
\quad 60\end{array}$ \\
\hline $\begin{array}{l}\text { 11. Quality of Life Rankings } \\
\text { (Slottje, 1991) }\end{array}$ & & $X$ & $X$ & $X$ & 126 \\
\hline $\begin{array}{l}\text { 12. Combined Quality of Life } \\
\text { Indices [CQLI] (Diener, 1995) }\end{array}$ & $\mathrm{X}$ & $\mathrm{X}$ & $X$ & $X$ & 77 \\
\hline $\begin{array}{l}\text { 13. Index of Economic } \\
\text { Freedom (Johnston \& Sheehy, } \\
\text { 1995) }\end{array}$ & & $\mathrm{X}$ & & & $\begin{array}{l}\text { More than } \\
100\end{array}$ \\
\hline $\begin{array}{l}\text { 14. Economic Freedom Indices } \\
\text { [EFIs] (Gwartney, Lawson, \& } \\
\text { Block, 1996) }\end{array}$ & & $\mathrm{X}$ & $\mathrm{X}$ & & 103 \\
\hline $\begin{array}{l}\text { 15. Human Development } \\
\text { Index [HDI] (UNDP, 1996) }\end{array}$ & & $\mathrm{X}$ & & $\mathrm{X}$ & 174 \\
\hline $\begin{array}{l}\text { 16. Gender-related } \\
\text { Development Index [GDI] } \\
\text { (UNDP, 1996) }\end{array}$ & & $\mathrm{X}$ & & $X$ & 163 \\
\hline $\begin{array}{l}\text { 17. Gender Empowerment } \\
\text { Measure [GEM] (UNDP, } \\
\text { 1996) }\end{array}$ & & $\mathrm{X}$ & $\mathrm{X}$ & $\mathrm{X}$ & 100 \\
\hline
\end{tabular}


(conclusion)

Table 1: Distribution of World Development Indices by Analysis

\begin{tabular}{|c|c|c|c|c|c|}
\hline \multirow{2}{*}{ Description } & \multicolumn{5}{|c|}{ Dimension } \\
\hline & Environmental & Economic & Political & Social & $\begin{array}{c}\text { Coverage } \\
\text { (Countries) }\end{array}$ \\
\hline $\begin{array}{l}\text { 18. Global Competitiveness } \\
\text { Indices (World Economic } \\
\text { Forum, 1996) }\end{array}$ & & $\mathrm{X}$ & $\mathrm{X}$ & $\mathrm{X}$ & 49 \\
\hline $\begin{array}{l}\text { 19. Human Poverty Index } \\
\text { [HPI-1] for developing } \\
\text { countries (UNDP, 1999) }\end{array}$ & & & & $\mathrm{X}$ & 92 \\
\hline $\begin{array}{l}\text { 20. Human Poverty Index } \\
\text { [HPI-2] for developed } \\
\text { countries (UNDP, 1999) }\end{array}$ & & $\mathrm{X}$ & & $\mathrm{X}$ & 17 \\
\hline $\begin{array}{l}\text { 21. Ecological Footprint } \\
\text { (Wackernagel \& Rees, 1996) }\end{array}$ & $X$ & $\mathrm{X}$ & & $\mathrm{X}$ & 52 \\
\hline $\begin{array}{l}\text { 22. Dashboard of sustainability } \\
\text { (International Institute for } \\
\text { Sustainable Development } \\
\text { [IISD], 2003) }\end{array}$ & $\mathrm{X}$ & $\mathrm{X}$ & & $\mathrm{X}$ & $\begin{array}{l}\text { More than } \\
\quad 200\end{array}$ \\
\hline $\begin{array}{l}\text { 23. Environmental } \\
\text { Sustainability Index (Yale } \\
\text { Center for Environmental Law } \\
\text { and Policy \& Center for } \\
\text { International Earth Science } \\
\text { Information Network, 2005) }\end{array}$ & $\mathrm{X}$ & $\mathrm{X}$ & $\mathrm{X}$ & $\mathrm{X}$ & 146 \\
\hline
\end{tabular}

Source: authors.

\section{Main National Indicators}

Twenty Brazilian indicators were selected based on the same criteria but exchanging international acceptance for national acceptance, as shown in Table 2 and analyzed because of the dimensions contained in them ${ }^{(7)}$.

Table 2: Distribution of Brazilian Development Indices by Analysis Dimension

\begin{tabular}{|c|c|c|c|c|}
\hline \multirow{2}{*}{ Description } & \multicolumn{4}{|c|}{ Dimension } \\
\hline & Environmental & Economic & Political & Social \\
\hline $\begin{array}{l}\text { 1. Cepal Poverty Line } \\
\text { (Comisión Económica para } \\
\text { América Latina [CEPAL], } \\
\text { 1991) }\end{array}$ & & $\mathrm{X}$ & & \\
\hline $\begin{array}{l}\text { 2. IBGE, IPEA and Cepal } \\
\text { Poverty Line (Árias, 1999) }\end{array}$ & & $\mathrm{X}$ & & \\
\hline $\begin{array}{l}\text { 3. Barometer of Sustainability } \\
\text { ( Prescott-Allen, 1997) }\end{array}$ & $\mathrm{X}$ & $\mathrm{X}$ & & $\mathrm{X}$ \\
\hline $\begin{array}{l}\text { 4. Genuine Progress Indicator } \\
\text { [GPI] (Cobb, Halstead, \& } \\
\text { Rowe, 1995) }\end{array}$ & $\mathrm{X}$ & $\mathrm{X}$ & & $\mathrm{X}$ \\
\hline $\begin{array}{l}\text { 5. Quality of Urban Life Index } \\
\text { [QULI] (Lemos, Esteves, \& } \\
\text { Simões, 1995) }\end{array}$ & $\mathrm{X}$ & & & $\mathrm{X}$ \\
\hline
\end{tabular}


(conclusion)

Table 2: Distribution of Brazilian Development Indices by Analysis Dimension

\begin{tabular}{|c|c|c|c|c|}
\hline \multirow{2}{*}{ Description } & \multicolumn{4}{|c|}{ Dimension } \\
\hline & Environmental & Economic & Political & Social \\
\hline $\begin{array}{l}\text { 6. Economic Development } \\
\text { Index (Secretaria do } \\
\text { Planejamento e } \\
\text { Desenvolvimento do Estado } \\
\text { de Goiás, 2005) }\end{array}$ & & $\mathrm{X}$ & & \\
\hline $\begin{array}{l}\text { 7. Economic Development } \\
\text { Index (Secretaria do } \\
\text { Planejamento e } \\
\text { Desenvolvimento do Estado } \\
\text { de Goiás, 2005) }\end{array}$ & $\mathrm{X}$ & $\mathrm{X}$ & & $\mathrm{X}$ \\
\hline $\begin{array}{l}\text { 8. IPEA Poverty Line (Rocha, } \\
\text { 2000) }\end{array}$ & & $X$ & & \\
\hline $\begin{array}{l}\text { 9. A Robust Poverty Profile } \\
\text { for Brazil Using Multiple Data } \\
\text { Sources (Ferreira, Lanjouw, \& } \\
\text { Neri, 2003) }\end{array}$ & & X & & $\mathrm{X}$ \\
\hline $\begin{array}{l}\text { 10. End of Hunger Map } \\
\text { (Fundação Getúlio Vargas } \\
\text { [FGV], 2001) }\end{array}$ & & $\mathrm{X}$ & & \\
\hline $\begin{array}{l}\text { 11. Economic Development } \\
\text { Index [EDI] (Superintendência } \\
\text { de Estudos Econômicos e } \\
\text { Sociais da Bahia [SEI], 2002) }\end{array}$ & & $\mathrm{X}$ & & $\mathrm{X}$ \\
\hline $\begin{array}{l}\text { 12. Social Development Index } \\
\text { [SDI] (SEI, 2002) }\end{array}$ & & & & $\mathrm{X}$ \\
\hline $\begin{array}{l}\text { 13. State of Pará Indicators } \\
\text { (Ribeiro, 2002) }\end{array}$ & $\mathrm{X}$ & $X$ & & $\mathrm{X}$ \\
\hline $\begin{array}{l}\text { 14. Urban Sustainability Index } \\
\text { [USI] (Braga, Freitas, \& } \\
\text { Duarte, 2002) }\end{array}$ & $\mathrm{X}$ & $\mathrm{X}$ & $X$ & $\mathrm{X}$ \\
\hline $\begin{array}{l}\text { 15. Social Exclusion Atlas } \\
\text { (Pochmann \& Amorim, 2003) }\end{array}$ & & $X$ & & $\mathrm{X}$ \\
\hline $\begin{array}{l}\text { 16. Geo Cities (Programa das } \\
\text { Nações Unidas para o Meio } \\
\text { Ambiente [PNUMA], 2002) }\end{array}$ & $\mathrm{X}$ & & & \\
\hline $\begin{array}{l}\text { 17. Socio-Economic } \\
\text { Development Index [SEDI] } \\
\text { (Fundação de Economia e } \\
\text { Estatística FEE, 2003) }\end{array}$ & $\mathrm{X}$ & $\mathrm{X}$ & & $\mathrm{X}$ \\
\hline $\begin{array}{l}\text { 18. Sustainable Development } \\
\text { Index [SDI] (Instituto } \\
\text { Brasileiro de Geografia e } \\
\text { Estatística [IBGE], 2004) }\end{array}$ & $\mathrm{X}$ & $X$ & & $X$ \\
\hline $\begin{array}{l}\text { 19. Poverty Mapping (Soares } \\
\text { \& Quintella, 2005) }\end{array}$ & & $\mathrm{X}$ & & $\mathrm{X}$ \\
\hline $\begin{array}{l}\text { 20. DNA-Brazil Index } \\
\text { (UNICAMP, 2005) }\end{array}$ & $\mathrm{X}$ & $\mathrm{X}$ & $\mathrm{X}$ & $\mathrm{X}$ \\
\hline
\end{tabular}

Source: authors. 
Analysis of the development indices and selected indicator systems' dimensions shows limitations regarding aspects considered relevant for this research. It should be highlighted that from the fortythree indicators analyzed in Tables 1 and 2, only four consider all of the developmental dimensions (environmental, economic, political and social) that are advocated in the literature reviewed. Even more surprising is the fact that the majority of them do not give references regarding the theoretical approach considered in its modelling, indicator selection, agglutination methods and, fundamentally, propositions related to the political dimension. This last item is absolutely predominant in the case of Brazilian indices.

The diversity of proposals, is, in itself a reason for the consensus that it is difficult to measure development. However, as we have seen, apart from the great variety, there is also wide disagreement in relation to defining the concept. Even more serious is the significant absence of information (perhaps not just by chance) on the methodological choices intrinsic to each one of the metrics.

The knowledge supplied by these development indices and indicator systems has the potential of objectively contributing to the process of organising an action agenda for political authorities. Nevertheless, it should also be a reason for concern, as it conceals the idiosyncrasies of each social group responsible for and interested in preparing and disseminating these metrics.

Each social group tends to establish distinct social relationships and interacts with the environment in different ways; the indiscriminate adoption of international solutions for measuring development, without due criticism, could have a supposed uniformity of standards and well-being of societies as a premise, even in the hypothesis that this is not deliberated or consciously adopted.

The rapid dissemination of development measurement proposals appears to be strengthened by adopting numbers (indices and indicators) and their respective aura of infallibility ${ }^{(8)}$ and universality, apart from simplified methodologies, which are sometimes incomplete and only rarely refer to the theoretical approaches adopted in them. All of these factors have corroborated a supposed and abstract ideological neutrality from establishing development rankings.

The indistinct adoption of indices or indicator systems will, in this way, not only have an interpretative function but also a strong forming influence. It will be able to contribute to the summary elimination of endogenous characteristics of people or regions and directly affect cultural diversity. It is clear that before adopting any development indicator, it is fundamental to previously know about the concept and methodologies adopted in its construction. However, a large part of the indicators (almost all of those presented here) are a result of proxies of income, socio-economic and environmental indicators. In other words, the most usual metrics are frequently a reunion of elements from distinct currents of thought and are therefore eventually incompatible (This hypothesis will be investigated in detail during the continuation of this research and will be shown in the next article).

An evaluation of adherence to the criteria adopted in this research for the forty-three development indicators leads us to observe that there are also various practical and conceptual problems related to the processes and measurement tools most usually employed when studying development.

A multidimensional and interdisciplinary approach, based on the studied authors, allowed for the identification of analysis dimensions common to all of the schools. These common dimensions are: Social, Economic, Political and Environmental. Analysis of these four dimensions provided an evaluation of adherence for the indicators studied, representing the process of accelerated social change in search of a state of well-being. This indicated obvious limitations for thirty-nine of these.

\section{FinAL CONSIDERATIONS}

According to the analysis that was carried out, the large majority of the main development indices studied only partially consider dimensions advocated in literature. The majority of them only respond 
to the social and economic dimensions and only observe some facets of the phenomenon that they aim to measure.

As previously mentioned in Section 6 above, although the analysis in this research is focused on a theoretical-conceptual approach, it is important to highlight that the use of indicators should be based on technical and pragmatic criteria. In order to contribute to the understanding of such aspects, a second paper discussing the limits and possibilities of development indexes and indicator systems is under preparation. This second paper will shed some light upon the four selected indicators considering all of the dimensions (environmental, economic, political and social) that are advocated in the literature reviewed. In order to do this, the internal consistency of those indicators will be evaluated, analyzing the adequacy and premises of their mathematical models as well as their relevance, intensity grading, univocity, standardization, traceability, stability, representativity and simplicity.

Inspired by reflections on Development Theory, therefore, the present paper sought to offer a differentiated approach through dialogue with distinct schools of thought. This exercise led to the identification of the main differences and similarities in development approaches and brought them together by current of thought. It was also noted that the schools converge in accepting the noun "wellbeing' as a desirable state of harmony both for the environment and man.

It was also seen that the developmental vision of a society cannot remain restricted to an operative and purely descriptive concept. This is related to induced hypotheses that culminate in a model of cultural standards that end up being strange to the societies in which they are applied.

It is important to emphasize that, even so, the development indicators of a wider theoretic scope must be viewed not only as tools for eventual or figurative use but as important elements to substantiate decision making in the public sphere. Therefore, choice of a development indicator to subsidize governmental decisions may represent adopting a mimetic and sometimes coercive model, potentially leading its adopters to consolidate foreign dependences as a necessary step to benefit from international development financing. These, in turn, are the very antithesis of development and in this way can inhibit the structural transformations of many economies and their societies.

In this way, the indices and system indicators prescribe norms and procedures for what is considered the normal development route. It is therefore concluded that a critical, inquisitive and interdisciplinary view is necessary to study and instrumentalize development through synthetic metrics. In turn, this paradigm demands the construction of analytical categories that integrate contributions from different fields of knowledge.

Finally, some evidence was given that construction of a good development indicator is rarely easily understood: in order for it to describe the complexity of the phenomenon, it apparently requires a correspondingly high level of internal complexity. It is necessary for scientists from the social, economic and environmental areas, supported by the technological infrastructure that is widely available in their respective areas of knowledge, to take on the responsibility of preparing explicit constructs. These should be simultaneously more eclectic and rigorous in terms of their methodological base and greater care should also be taken with the use and communication of results obtained by existing metrics.

\section{NOTES}

\footnotetext{
${ }^{1}$ An inflection point on the growth curve for adaptation to natural laws or God's plan.

${ }^{2}$ Rousseau glorifies the values of natural life and attacks civil society's vices. The good savage myth is associated to the idea of the native's greater perfectibility and purity of his natural state, in opposition to the falsehood and artificiality of civilized man.
} 


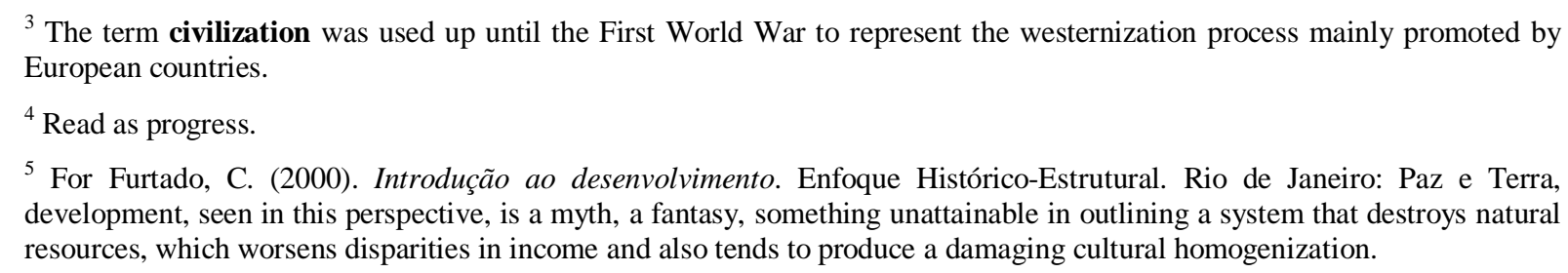

${ }^{6}$ Apart from the experiences analyzed, the following indicators should also be quoted: World Value Survey from 1981 (World Value Survey (2006). Documentation of the values surveys. Retrieved July 10, 2006, from http://www.worldvaluessurvey.org); German Socio-Economic Panel Study from 1984 (Deutsches Institut für Wirtschaftsforschung. (2004). German socio-economic panel study. Retrieved July 30, 2005, from http://www.diwberlin.de/deutsch/soep/26628.html); World Bank poverty index 1990 (World Bank. (2005). Poverty index. Retrieved July 10, 2005, from http://web.worldbank.org); Cepal poverty line from 1991 (Comisión Económica para América Latina. (2005). Anuario estadístico. Retrieved June 18, 2005, from http://web.worldbank.org).

${ }^{7}$ Apart from the work presented here, the following should also be mentioned: The Well-Being Index (Tolosa, H. C., \& Rocha, S. (1993). Núcleo-periferia metropolitana: diferenciais de renda e pobreza. In J. P. dos Reis Velloso \& R. C. de Albuquerque (Orgs.). Pobreza e mobilidade social. Rio de Janeiro: Editora Nobel); Basic needs index (Albuquerque, R. C. de (1995). Estratégia de desenvolvimento e combate à pobreza. Estudos Avançados, 9(24). Retrieved June 18, 2005, from http://www.scielo.br/scielo.php?script=sci_arttext\&pid=S0103-40141995000200004\&lng=en\&nrm=iso); Mobility index (Pastore, J., \& Haller, A. (1993). O que está acontecendo com a mobilidade social no Brasil. In J. P. dos R. Velloso \& R. C. de Albuquerque (Orgs.). Pobreza e mobilidade social. São Paulo: Nobel); Quality of Life (Almeida, A. C. M. (1997). A qualidade de vida no estado do Rio de Janeiro. Niterói: Eduff) and Economic and social development index (Superintendência de Estudos Econômicos e Sociais da Bahia. (2000). Índices de desenvolvimento econômico e social dos municípios baianos. Retrieved July 28, 2005, from http://www.sei.ba.gov.br).

${ }^{8}$ Skovsmose, O. (2005). Travelling through education: uncertainty, mathematics, responsibility. Rotterdam: Sense Publishers, classifies belief in the infallibility of quantification and in turn, of mathematics as an ideology of certainty, which represents a dogmatic element and is shown through a supernatural reverence for numbers.

\section{REFERENCES}

Almeida, J. A. (1999). A problemática do desenvolvimento sustentável. In D. F. Becker (Org.). Desenvolvimento sustentável: necessidade ou possibilidade. Santa Cruz do Sul: Edunisc.

Almeida, P. R. (1994). A cláusula social no comércio internacional. RBCE Comércio Exterior, (40), 52-60.

Árias, A. R. (1999). Estimativas de indigência e pobreza no Brasil no período 1990-1996: resumo metodológico e resultados. Brasília: IPEA.

Beck, U. (1997). Die eröffnung des welthorizontes: zur soziologie der globalisierung. Baden Baden: Nomos.

Becker, B. K. (1993). A Amazônia pós ECO-92: por um desenvolvimento regional responsável. In M. Bursztyn (Org.). Para pensar o desenvolvimento sustentável. Brasília: IBAMA/ENAP/ Brasiliense.

Beckerman, W., \& Bacon, R. (1966). International comparisons of income levels: a suggested new measure. Economic Journal, 76(303), 519-536.

Bennett, M. K. (1951). International disparities in consumption levels. American Economic Review, 41(4), 632-649.

Braga, T. M., Freitas, A. G., \& Duarte, G. S. (2002). Índice de sustentabilidade urbana. Encontro da Associação Nacional de Pós-Graduação e Pesquisa em Ambiente e Sociedade, São Paulo, SP, Brasil, 1.

Bustelo, P. (1999). Teorías contemporâneas del desarrollo económico. Madrid: Editorial Sínteses. 
Camino, R., \& Müller, S. (1993). Sostenibilidad de la agricultura y los recursos naturales: bases para estabelecer indicadores (Série Documentos de Programas IICA, 38). San José: IICA.

Castells, M. (2000). A era da informação: economia, sociedade e cultura. São Paulo: Paz e Terra.

Comissão Econômica para a América Latina e o Caribe. (1991). Magnitud de la pobreza en América Latina en los años ochenta (Estudos e Informes de la CEPAL, $\mathrm{n}^{\circ}$ 81). Santiago de Chile, Chile: Author.

Cobb, C., Halstead, T., \& Rowe, J. (1995). The genuine progress indicator: summary of data and methodology. San Francisco: Redefining Progress.

South Commision. (1990). Rapport de la commision, défis au sud. Paris: Economica.

Darolt, M. R. (2000). As dimensões da sustentabilidade: um estudo da agricultura orgânica na região metropolitana de Curitiba-PR. Tese de Doutorado. Universidade Federal do Paraná, Curitiba, PR, Brasil.

Diener, E. (1995). A value based index for measuring national quality of life. Social Indicators Research, 36(2), 107-127.

Duchet, M. (1984). Le partage des savoirs - discours historique, discours ethnologique. Paris: Editions La Découverte.

Estes, R. J. (1984). The social progress of nations. New York: Praeger.

Fundação de Economia e Estatística. (2003). Índice de desenvolvimento socioeconômico (IDESE). Porto Alegre: FEE.

Ferreira, F. H. G., Lanjouw, P., \& Neri, M. C. (2003). A robust poverty profile for Brazil using multiple data sources. Revista Brasileira de Economia, 57(1), 59-92.

Fundação Getúlio Vargas. (2001). Mapa do fim da fome. Rio de Janeiro: Author.

Furtado, C. (1974). O mito do desenvolvimento econômico. São Paulo: Paz e Terra.

Ginsberg, N., Osborn, J., \& Blank, G. (1986). Geographic perspectives on the wealth of nations. Chicago: University of Chicago.

Gwartney, J., Lawson, R., \& Block, W. (1996). Economic freedom of the world (1975-1995). Johannesburg: Free Market Foundation.

Harbison, F., \& Myers, C. A. (1964). Education, manpower, and economic growth. New York: McGraw-Hill.

Hart, R. (1994). Summary, conclusions and lesson learned from the SANRM/ INFORUM Eletronic Conference on Indicators of Sustainability. Retrieved May 14, 2006, from http://tdg.uoguelph.ca/www/FSR/collection/indicator/summary02.txt

Hess, P. (1989). The military burden, economic growth, and the human suffering index: evidence from the LDCs. Cambridge Journal of Economics, 13(4), 497-515.

Hodge, T., Holtz, S., Smith, C., \& Baxter, K. H. (1995). Pathways to sustainability: assessing our progress. Ottawa: NRTEE.

Holtz, S. (1995). Approaches to reporting on human well-being. In T. Hodge, S. Holtz, C. Smith, \& K. Baxter (Eds.). Pathways to sustainability: assessing our progress. Ottawa: NRTEE. 
Instituto Brasileiro de Geografia e Estatística. (2004). Indicadores de desenvolvimento sustentável. Rio de Janeiro: Author.

International Institute for Sustainable Development. (2003). The dashboard of sustainability. Manitoba, Canada: Author

Imbach, A., Dudley, E., Ortiz, N., \& Sánchez, H. (1997). Mapeo analítico, reflexivo y participativo de la sostenibilidad-MARPS. Cambidge: UICN.

Jannuzzi, P. M. (2001, setembro). Repensando a prática de uso de indicadores sociais na formulação e avaliação de políticas públicas municipais. Anais do Encontro Nacional da Associação Nacional de Pós-Graduação e Pesquisa em Administração, Campinas, SP, Brasil, 25.

Johnston, B. T., \& Sheehy, T. P. (1995). The index of economic freedom. Washington: Heritage Foundation.

Lemos, M. B., Esteves, O. A., \& Simões, R. F. (1995) Uma metodologia para construção de um índice de qualidade de vida urbana. Nova Economia, 5(2), 157-176.

Lopes, S. B. (2001). Arranjos institucionais e a sustentabilidade de sistemas agroflorestais: uma proposição metodológica. Dissertação de Mestrado. Universidade Federal do Rio Grande do Sul, Porto Alegre, RS, Brasil.

McGranahan, D. V., Richard-Proust, C., Sovani, N. V., \& Subramanian, M. (1972). Contents and measurement of socioeconomic development. New York: Praeger.

Matos, C. (1997). Desenvolvimento sustentável nos territórios da globalização: alternativa de sobrevivência ou nova utopia? In B. K. Becker \& M. Miranda (Orgs). A geografia política do desenvolvimento sustentável. Rio de Janeiro: Editora UFRJ.

Marzall, K., \& Almeida, J. (1998). Parâmetros e indicadores de sustentabilidade na agricultura: limites, potencialidades e significado no contexto do desenvolvimento rural. Extensão Rural, 5, 25-32.

Maxwell, S. (1999, February 3). The meaning and measurement of poverty. Poverty Briefin. Retrieved January 10, 2004, from http://www.odi.org.uk/publications/briefing/pov3.html

Morris, M. D. (1979). Measuring the condition of the world's poor: the physical quality of life index (Pergamon Policy Studies nº 42, pp. 20-56). New York: Pergamon Press.

Naredo, J. M. (1987). Qué pueden hacer los economistas para ocuparse de los recursos naturales? Desde el Sistema Económico hacia la Economía de los Sistemas. Pensamiento Iberoamericano, 12(2), 61-74.

Noll, H. H., \& Zapf, W. (1994). Social indicators research: societal monitoring and social reporting. In I. Borg \& P. Ph. Mohler (Orgs.). Trends and perspectives in empirical social research. Berlin: Gruyter.

Programa das Nações Unidas para o Meio Ambiente. (2002) Projeto GEO Cidades (Relatório Ambiental Urbano Integrado). Rio de Janeiro, RJ: Consórcio Parceria 21.

Pochmann, M., \& Amorim, R. G. (2003). Atlas da exclusão social no Brasil. São Paulo: Cortez.

Prescott-Allen, R. (1997). Barometer of sustainability: measuring and communicating wellbeing and sustainable development. Cambridge: IUCN.

Prescott-Allen, R. (2001). The wellbeing of nations: a country-by-country index of quality of life and the environment. Washington: Island Press.

Preston, P. W. (1996). Development theory: an Introduction. Oxford: Blackwell Publishers. 
Ram, R. (1982). Composite indices of physical quality of life, basic needs fulfilment, and income: a principal component representation. Journal of Development Economics, 11(2), 227-247.

Raynaut, C. (1997). Les sabels: diversité et dynamiques des relations sociétés-natures. Paris: Kartjal.

Raynaut, C., Lana, P., \& Zanoni, M. (2000). Pesquisa e formação na área de meio ambiente e desenvolvimento: novos quadros de pensamento, novas formas de avaliação. Desenvolvimento $e$ meio ambiente, (1), 71-81.

Ribeiro, A. L. (2002). Modelo de indicadores para mensuração do desenvolvimento sustentável na Amazônia. Tese de doutorado. Universidade Federal do Pará, Belém, PA, Brasil.

Ribeiro, M. T. F. (2005). Notas de aula do curso de doutorado em administração [Notas de aula]. Escola de Administração, Universidade Federal da Bahia, Salvador, Bahia, Brasil.

Rist, G. (2001). Le developement : une histoire de croyance ocidentale. Paris: Presses de Science Po.

Rivero, O. (2002). O mito do desenvolvimento. Os países inviáveis no século XXI. Petrópolis: Vozes.

Rocha, S. (2000). Estimação de linhas de indigência e de pobreza: opções metodológicas no Brasil. In R. O. Henriques (Ed.). Desigualdade e pobreza no Brasil (pp. 109-127). Rio de Janeiro: IPEA.

Rostow, W. W. (1971). Etapas do desenvolvimento econômico. Rio de Janeiro: Zahar Editores.

Sachs, I. (2004). Desenvolvimento: includente, sustentável, sustentado. Rio de Janeiro: Garamond.

Santagada, S. (1993). Indicadores sociais: contexto social e breve histórico. Indicadores Econômicos, $4(20), 245-255$.

Schumpeter, J. (1984). Capitalismo, socialismo e democracia. Rio de Janeiro: Zahar Editores. (Obra original publicada em 1942).

Schumpeter, J. (1985). A teoria do desenvolvimento econômico. São Paulo: Nova Cultural. (Obra original publicada em 1911).

Schumpeter, J. (1989). Business cycles: a theoretical, historical and statistical analysis of the capitalist process. Philadelphia: Porcupine. (Obra original publicada em 1939).

Sen, A. K. (1976). Poverty: an ordinal approach to measurement. Econometrica, 44, 219-231.

Slottje, D. J. (1991). Measuring the quality of life across countries. Review of Economics and Statistics, 73(4), 684-693.

Smith, A., \& Ricardo, D. (1978). Riqueza das nações. Princípios de economia política. Salvador: Abril Cultural.

Soares, J. S., Jr., \& Quintella, R. H. (2002). Indicadores sociais de baixo custo e sua utilidade na gestão da interface entre os governos estadual e municipal. Organizações e Sociedade, 9(25), 45-60.

Soares, J. S., Jr., \& Quintella, R. H. (2005). Descoberta de conhecimento em bases de dados públicas: uma proposta de estruturação metodológica. Revista de Administração Pública, 39(5), 10771107.

Sunkel, O. (2001). A sustentabilidade do desenvolvimento atual. In: G. Arbix, M. Zilbovicius \& R. Abramovay (Ed.). Razões e ficções do desenvolvimento. São Paulo: Editora UNESP \& EDUSP.

Superintendência de Estudos Econômicos e Sociais da Bahia. (2002). Índices de desenvolvimento econômico e social. Salvador: Author. 
Taylor, C. L., \& Jodice, D. A. (1983). World handbook of political and social indicators. New Haven: Yale University Press.

Tironi, L. F., Silva, L. C. E. Silva, Vianna, S. M., \& Médici, A. C. (1991). Critérios para geração de indicadores de qualidade e produtividade no serviço público. Brasília: IPEA/MEFP.

Truman, H. S. (1949). Inaugural address of Harry S. Truman. Retrieved April 15, 2008, from http://www.yale.edu/lawweb/avalon/presiden/inaug/truman.htm

Trzesniak, P. (1998). Indicadores quantitativos: reflexões que antecedem seu estabelecimento. Brasília: Revista de Ciência da Informação, 27(2), 159-164.

Universidade Estadual de Campinas. (2005). Índice DNA-Brasil. Retrieved January 25, 2006, from http://www.dnabrasil.org.br

United Nations Development Programme. (1991). Human development report. New York: Oxford University Press.

United Nations Development Programme. (1996). Human development reports 1996. New York: Oxford University Press.

United Nations Development Programme. (1999). Human development reports 1999. New York: Oxford University Press.

Veiga, J. E. (2005). Desenvolvimento sustentável: o desafio do século XXI. Rio de Janeiro: Garamond.

Wackernagel, M., \& Rees, W. (1996). Our ecological footprint: reducing human impact on the earth.t. Gabriola Island, BC and Stony Creek, CT: New Society Publishers.

World Economic Forum. (1996). Global competitiveness report. Geneva: Author.

Yale Center for Environmental Law and Policy \& Center for International Earth Science Information Network. (2005). Environmental Sustainability Index: Benchmarking National Environmental Stewardship. New Haven, U.S.: Author, Yale University and New York, U.S.: Author, Columbia University. 